\title{
CHARACTERISTICS OF CARBON DIOXIDE AND PRODUCT WATER EXHAUSTS IN A DIRECT METHANOL FUEL CELL WITH SERPENTINE CHANNELS
}

\author{
Kohei Nakashima \\ Meijo University \\ Department of Vehicle and Mechanical Engineering \\ 1-501 Shiogamaguchi, Tempaku-ku, Nagoya 468-8502, Japan \\ tel.: +8152 8321151, fax: +81528321235 \\ e-mail:nakasima@meijo-u.ac.jp
}

\begin{abstract}
This study utilized a transparent direct methanol fuel cell, with serpentine channels with a width of $2 \mathrm{~mm}$ and an initial depth of $2 \mathrm{~mm}$, and investigated the relationship between the behaviours of carbon dioxide (CO $\left.\mathrm{C}_{2}\right)$ slugs, product water accumulations, and voltage fluctuation. It examined the exhaust volumes of $\mathrm{CO}_{2}$ slugs and product water accumulations from the channels over time, comparing an anode channel with a depth of $1.2 \mathrm{~mm}$ to one with a depth of $2 \mathrm{~mm}$ (without changing the cathode depth of $2 \mathrm{~mm}$, nor the width of $2 \mathrm{~mm}$ in both the anode and the cathode). Results indicated that cell voltage fluctuated, rising while $\mathrm{CO}_{2}$ slugs were ejected, and falling between ejections. In the case of an anode channel depth of $2 \mathrm{~mm}$ and a lower methanol-water solution flow rate, $\mathrm{CO}_{2}$ slugs were ejected less frequently, so cell voltage fluctuated widely. (Product water accumulations in the cathode had a minimum effect on this cell voltage fluctuation.) In the case of a higher methanol-water solution flow rate, $\mathrm{CO}_{2}$ slugs were ejected more frequently, with less exhaust volume per $\mathrm{CO}_{2}$ slug, reducing the fluctuation in cell voltage. Finally, with an anode channel depth of $1.2 \mathrm{~mm}$, the exhaust volume per $\mathrm{CO}_{2}$ slug became even smaller, and these small CO slugs were rapidly ejected. With this shallow depth, the cell voltage increased with a lower methanol-water solution flow rate, but decreased with a higher methanol-water solution flow rate by crossover.
\end{abstract}

Keywords: direct methanol fuel cell, bubble of carbon dioxide, slug of carbon dioxide, product water, transparent cell, serpentine channel

\section{Introduction}

A direct methanol fuel cell (DMFC) produces carbon dioxide $\left(\mathrm{CO}_{2}\right)$ gas bubbles at its anode, and water droplets at its cathode, by an electrochemical reaction. In the anode channel, $\mathrm{CO}_{2}$ gas bubbles grow, and coalesce into larger gas slugs [1-12]. In the cathode channel, water droplets expand and eventually accumulate [4]. These waste reaction products in the channels may inhibit the mass transfer of methanol and oxygen to the electrodes, decreasing cell voltage. One report investigated this fluctuation of cell voltage when the $\mathrm{CO}_{2}$ slug passes through a predetermined area of the anode channel, using a DMFC with a single, straight channel in the anode, and another in the cathode [2]. However, no report has examined the relationship between cell voltage fluctuation and the behaviour of the $\mathrm{CO}_{2}$ slugs in the entire anode channel. This study utilized a transparent DMFC [7-9] with serpentine channels with a depth of $2 \mathrm{~mm}$ and a width of $2 \mathrm{~mm}$ in both the anode and the cathode, to investigate the relationship between the behaviour of the $\mathrm{CO}_{2}$ slugs in the anode channel as well as the product water accumulations in the cathode channel, and cell voltage fluctuation, all with a higher current density, while varying the flow rates of methanolwater solution and air. Then, to focus on the exhaust behaviour of $\mathrm{CO}_{2}$ slugs, anode channels with depths of $2 \mathrm{~mm}$ and of $1.2 \mathrm{~mm}$ were compared, examining the exhaust volumes of the $\mathrm{CO}_{2}$ slugs and the product water accumulations from channels against time, as well as the cell power performance, again varying the flow rates of methanol-water solution and air. 


\section{Experimental apparatus and method}

Figure 1 shows the transparent DMFC, with an active area of $4 \mathrm{~cm}^{2}$, comprising a membrane electrode assembly (MEA), gaskets, separators, gaskets with serpentine channels, and end plates [7-9]. In the MEA, a solid polymer electrolyte membrane (Nafion 112) with a thickness of $50 \mu \mathrm{m}$ was coated on either side with catalysed electrodes, which were supported with gas diffusion layers made of carbon paper with a thickness of $0.37 \mathrm{~mm}$ (Toray TGP-H-120). For the anode catalyst layer, loading of Pt:Ru 1:1 was $3 \mathrm{mg} / \mathrm{cm}^{2}$, and for the cathode catalyst layer, loading of only Pt was $1 \mathrm{mg} / \mathrm{cm}^{2}$. The separators in both the anode and the cathode were made of carbon with a gas-impermeable treatment, and had serpentine through-channels with a width of $2 \mathrm{~mm}$, a lateral length of $18 \mathrm{~mm}$, and a rib width of $2 \mathrm{~mm}$. Separators initially had a channel depth (or thickness) of $2 \mathrm{~mm}$ in both the anode and the cathode, to investigate the relationship between the behaviours of the $\mathrm{CO}_{2}$ slugs in the anode channel and the product water accumulations in the cathode channel on cell voltage fluctuation. Based on those results, subsequent anode separators had a channel depth of either $2 \mathrm{~mm}$ or $1.2 \mathrm{~mm}$, to examine the exhaust volumes of the $\mathrm{CO}_{2}$ slugs and the product water accumulations from channels against time as well as cell power performance. These separators not only contain the flow channels, but also play the role of current collector plates. The anode end plate was made of vinyl chloride; the cathode end plate, acrylic.

Figure 2 shows the experimental apparatus. A chemical pump regulated the flow of methanol solution from a tank, and a mass flow controller regulated the flow of air from a gas cylinder, both connected directly to our DMFC. Temperature was maintained by a jig with heaters above the DMFC and a hot plate below. The DMFC was connected to an electric load device, to evaluate its performance by measuring polarization and current transients.

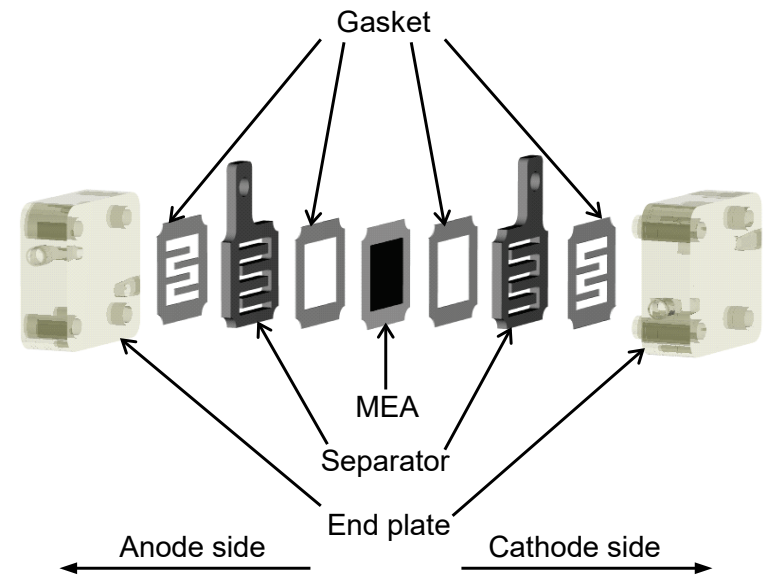

Fig. 1. Experimental transparent DMFC

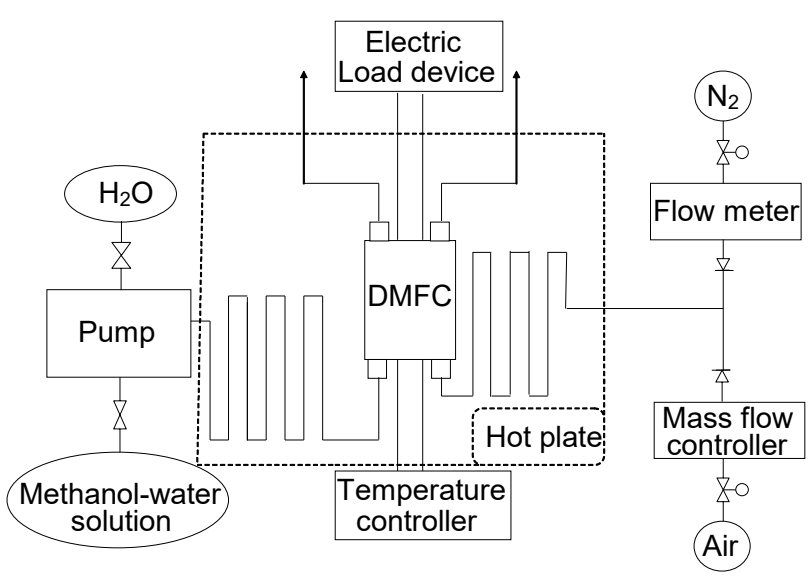

Fig. 2. Experimental apparatus

Cell temperature was set at $60^{\circ} \mathrm{C}$. Methanol solution ( $3 \mathrm{wt} \%$ ) was supplied in an upward flow at rates of $0.14 \mathrm{~mL} / \mathrm{min}$ and $0.28 \mathrm{~mL} / \mathrm{min}$, and air was supplied in a downward flow at rates of $18 \mathrm{~mL} / \mathrm{min}$ and $36 \mathrm{~mL} / \mathrm{min}$. Before the experiments, the DMFC was stabilized for one hour at a current density of $1.25 \mathrm{~mA} / \mathrm{cm}^{2}$. During the experiments, polarization curves were plotted by measuring the cell voltage while increasing the current density in increments of $1.25 \mathrm{~mA} / \mathrm{cm}^{2}$. When the cell voltage dropped below $0.4 \mathrm{~V}$, a video camera observed the behaviours of $\mathrm{CO}_{2}$ bubbles and slugs in the anode channel and product water droplets and accumulations in the cathode channel, as the current density continued to increase in increments of $1.25 \mathrm{~mA} / \mathrm{cm}^{2}$ every five minutes. To investigate the cell voltage fluctuation, voltage was measured every second. Cell power performance was evaluated from cell voltage immediately after the $1.25 \mathrm{~mA} / \mathrm{cm}^{2}$ increase in current density. Image analysis of the observation results calculated the volume of $\mathrm{CO}_{2}$ slugs and product water accumulations ejected from the channels through the exhaust ports. 


\section{Results and discussion}

\subsection{Relationship between behaviours of $\mathrm{CO}_{2}$ slugs and product water accumulations and cell voltage fluctuation}

Figure 3 shows the cell voltage fluctuation after the voltage dropped below $0.4 \mathrm{~V}$, with a methanol solution flow rate of $0.14 \mathrm{~mL} / \mathrm{min}$ and an air flow rate of $18 \mathrm{~mL} / \mathrm{min}$, with both anode and cathode depths of $2 \mathrm{~mm}$. In Fig. 3, the cell voltage fluctuates widely. Fig. 3 also shows the observed results of $\mathrm{CO}_{2}$ bubbles and slugs in the anode channel when the cell voltage fluctuated. In the anode channel, $\mathrm{CO}_{2}$ bubbles were produced, and attached to the channel; then several bubbles coalesced, growing in the size to the width of the channel. Then, propelled by the flow of methanol solution, these larger bubbles coalesced into gas slugs, which then coalesced into progressively larger slugs. These larger slugs occasionally remained in the channel for some time but then eventually flowed toward the exhaust port and were ejected. Here, when the cell voltage started to drop suddenly, the $\mathrm{CO}_{2}$ slug finished ejecting from the channel through the exhaust port (1). At that time, other slugs remained in the channel or flowed toward the exhaust port. Next, as the cell voltage began to rise, another slug began to exhaust through the exhaust port (2). Finally while the slug was exhausted through the exhaust port (3), the cell voltage rose, even if there were other slugs in the channel. These phenomena (1) to (3) were repeated. Under these experimental conditions, the time lengthened between $\mathrm{CO}_{2}$ slug ejections, during which the cell voltage dropped significantly. Then, voltage greatly increased, since the ejected slug was larger, and the time from the start to the end of discharge was longer. As a result, the voltage fluctuated widely. It seems that, while the slug is being exhausted, pressure in the channel increases, the mass transfer of methanol to the electrode is promoted, and thus cell voltage increases. Not shown in a figure, in the cathode channel, the water droplets remained, expanded, and accumulated. By the airflow, a larger product water accumulation was eventually ejected from the channel at once, swallowing multiple water droplets on the downstream side. These product water accumulations and behaviours had a minimal effect on cell voltage fluctuation.

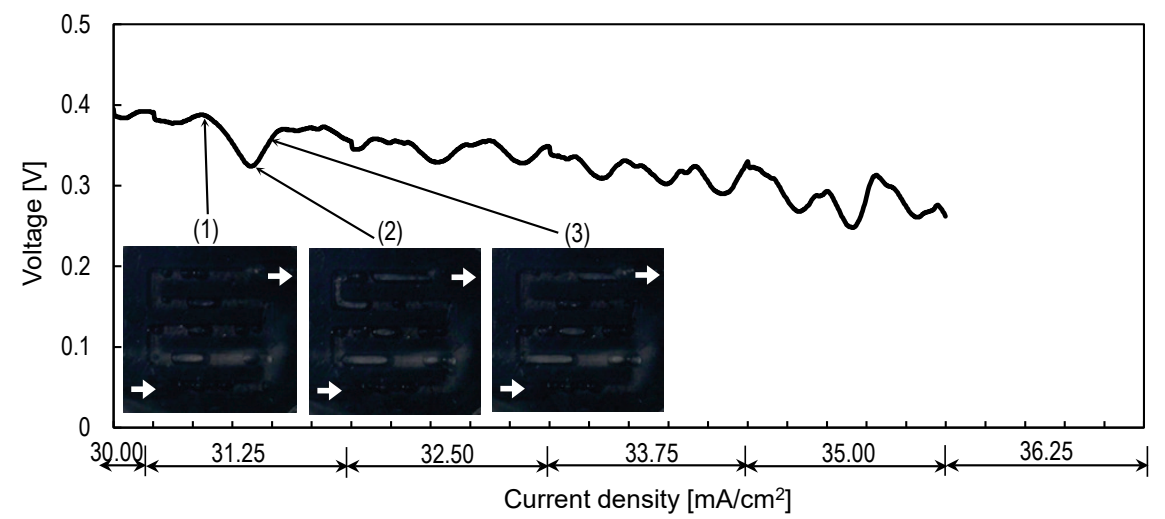

Fig. 3. Cell voltage fluctuation after voltage dropped below $0.4 \mathrm{~V}$, and behaviours of $\mathrm{CO}_{2}$ bubbles and slugs in anode channel, with methanol solution flow rate of $0.14 \mathrm{~mL} / \mathrm{min}$ and air flow rate of $18 \mathrm{~mL} / \mathrm{min}$ with both anode and cathode depths of $2 \mathrm{~mm}$

Figure 4 shows the cell voltage fluctuation after the voltage dropped below $0.4 \mathrm{~V}$, with a doubled methanol solution flow rate of $0.28 \mathrm{~mL} / \mathrm{min}$ and the same air flow rate of $18 \mathrm{~mL} / \mathrm{min}$, with both anode and cathode depths of $2 \mathrm{~mm}$. When this methanol solution flow rate increased, the cell voltage fluctuation decreased. Fig. 4 also shows the observed results of $\mathrm{CO}_{2}$ bubbles and slugs in the anode channel when the cell voltage fluctuated. With a higher methanol solution flow rate, again, when the $\mathrm{CO}_{2}$ slug finished ejecting from the channel through the exhaust port (1), the cell voltage started to drop, and then as the slug began to exhaust through the exhaust port (2), the cell 
voltage began to rise, and while the slug was exhausted through the exhaust port (3), the cell voltage rose. With a higher methanol solution flow rate, the $\mathrm{CO}_{2}$ slugs were smaller in the channel, the time between $\mathrm{CO}_{2}$ slug ejections became shorter, and the rate of $\mathrm{CO}_{2}$ slugs ejected from the exhaust port increased. Again, it was confirmed that, in the cathode channel, product water accumulations and behaviours had a minimal effect on the voltage fluctuation.

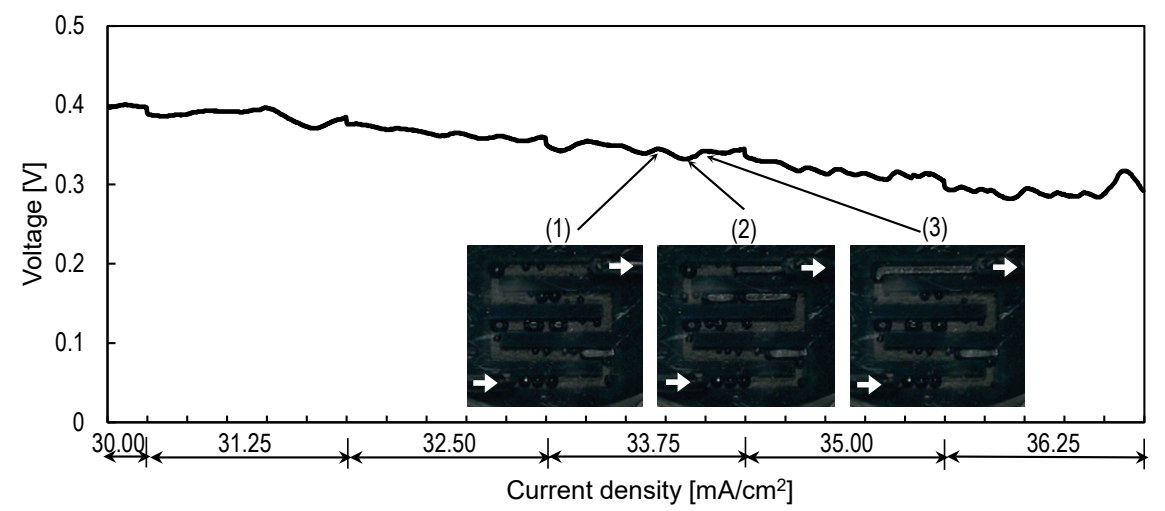

Fig. 4. Cell voltage fluctuation after voltage dropped below $0.4 \mathrm{~V}$, and behaviours of $\mathrm{CO}_{2}$ bubbles and slugs in anode channel, with methanol solution flow rate of $0.28 \mathrm{~mL} / \mathrm{min}$ and air flow rate of $18 \mathrm{~mL} / \mathrm{min}$ with both anode and cathode depths of $2 \mathrm{~mm}$

Therefore, in order to reduce cell voltage fluctuation, the anode should be designed such that the time between $\mathrm{CO}_{2}$ slug ejections should be shortened, and the rate of $\mathrm{CO}_{2}$ slugs ejected from the exhaust port should be increased.

\subsection{Exhaust volumes of $\mathrm{CO}_{2}$ slugs and product water accumulations from channels and cell power performance}

Section 3.1 above explained that the exhaust of $\mathrm{CO}_{2}$ slugs from the anode channel greatly affected the cell voltage fluctuation. Therefore, the next investigation focussed on measuring the volume of $\mathrm{CO}_{2}$ slugs ejected from the anode channel over time, as well as the cell power performance, comparing channels with a depth of $2 \mathrm{~mm}$ or $1.2 \mathrm{~mm}$ in the anode (but a constant $2 \mathrm{~mm}$ in the cathode), varying the flow rates of methanol solution and air. In addition, the volume of product water accumulations ejected from the cathode channel against time was measured. The MEA was replaced from the one used in the experiment reported in section 3.1.

Figure 5 shows cell power performance with both anode and cathode depths of $2 \mathrm{~mm}$. At lower flow rates of both methanol solution and air, the cell voltage decreased at higher current densities. Except at lower flow rates, varying the flow rates of methanol solution and air hardly changed cell power performance.

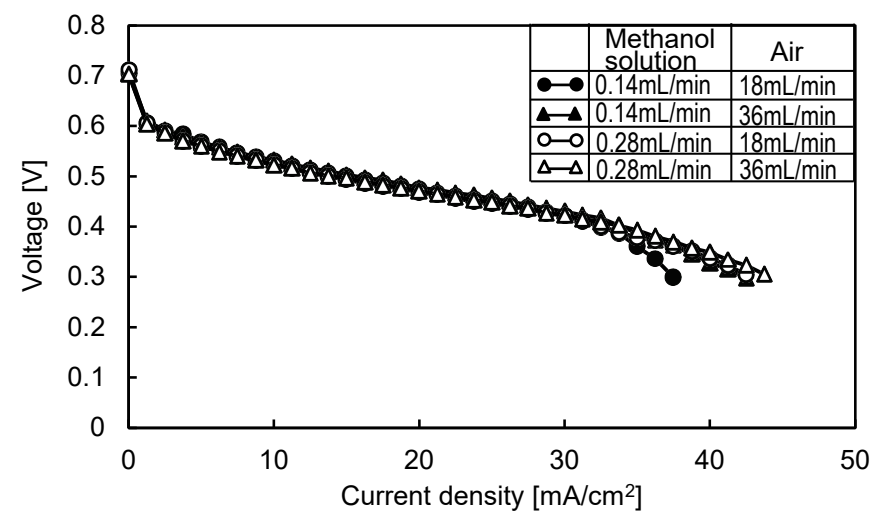

Fig. 5. Cell power performance with both anode and cathode depths of $2 \mathrm{~mm}$ 
Figures 6 and 7 show the exhaust volumes of $\mathrm{CO}_{2}$ slugs and product water accumulations, with both anode and cathode depths of $2 \mathrm{~mm}$, respectively. Here, assuming that the cross section of each channel would be filled with $\mathrm{CO}_{2}$ slugs and product water accumulations, the exhaust volumes of $\mathrm{CO}_{2}$ slugs and product water accumulations were obtained by multiplying their exhaust length by the cross-sectional area of the channel. In Fig. 6, with the increased methanol solution flow rate, the exhaust volume per $\mathrm{CO}_{2}$ slug decreased. It appears that, $\mathrm{CO}_{2}$ bubbles tend not to coalesce as the methanol solution flow rate increases. In Figs. 6 and 7, with a lower methanol solution flow rate and a higher airflow rate, the electrode reaction becomes active, and then the exhaust volumes of both $\mathrm{CO}_{2}$ slugs and water accumulations per unit time increased. Relative to this flow rate, when the methanol solution flow rate increased, the exhaust volume of $\mathrm{CO}_{2}$ slugs per unit time decreased. It is thought that crossover occurred when the methanol solution flow rate increased. With a higher methanol solution flow rate and a lower airflow rate, the exhaust volume of water accumulations per unit time increased. With this higher methanol solution flow rate and lower airflow rate, the methanol solution by crossover may be contained in the exhaust volume of water accumulation. It is considered that crossover decreases with higher flow rates of methanol solution and air. With higher flow rates of methanol solution and air, the exhaust volume of water accumulations per unit time decreased. It seems that, with a higher airflow rate, the droplets did not remain in the cathode channel, and was ejected with the airflow.

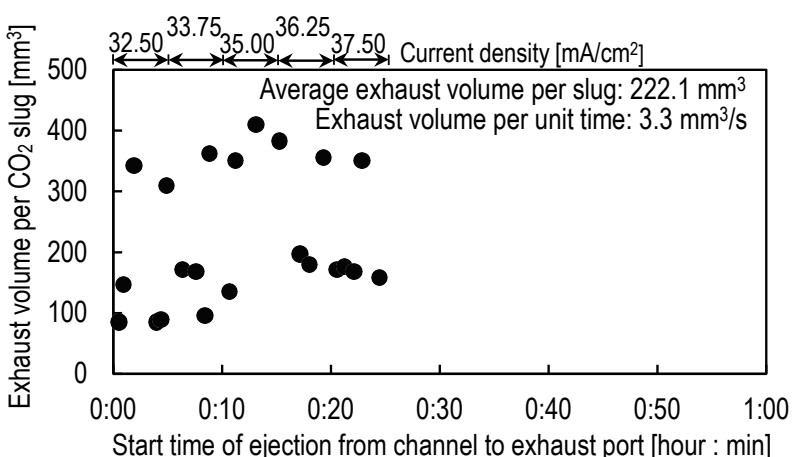

(a) Methanol solution $0.14 \mathrm{~mL} / \mathrm{min}$, air $18 \mathrm{~mL} / \mathrm{min}$

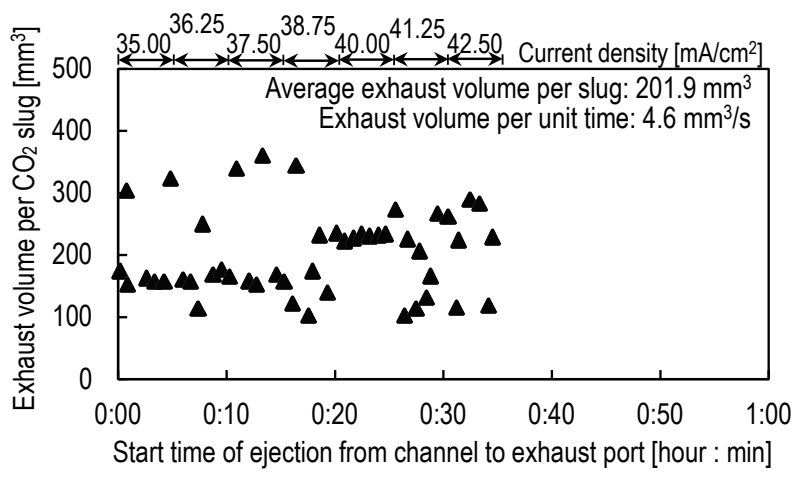

(c) Methanol solution $0.14 \mathrm{~mL} / \mathrm{min}$, air $36 \mathrm{~mL} / \mathrm{min}$

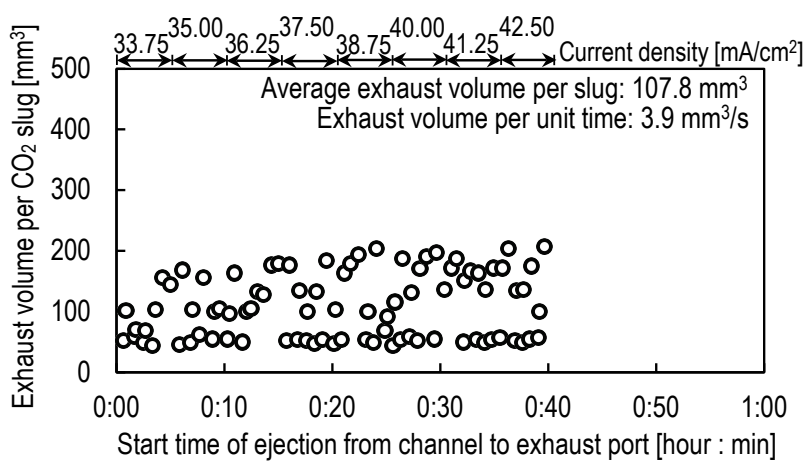

(b) Methanol solution $0.28 \mathrm{~mL} / \mathrm{min}$, air $18 \mathrm{~mL} / \mathrm{min}$

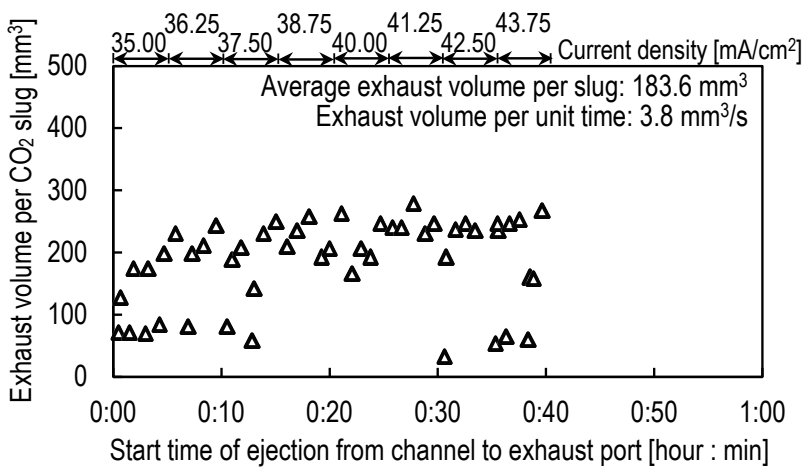

(d) Methanol solution $0.28 \mathrm{~mL} / \mathrm{min}$, air $36 \mathrm{~mL} / \mathrm{min}$

Fig. 6. Exhaust volume of $\mathrm{CO}_{2}$ slugs with both anode and cathode depths of $2 \mathrm{~mm}$

Figure 8 shows cell power performance with an anode depth of $1.2 \mathrm{~mm}$ and a cathode depth of $2 \mathrm{~mm}$. When the methanol solution flow rate increased, the cell voltage decreased, in each airflow rate. Compared with both anode and cathode depths of $2 \mathrm{~mm}$ (in Fig. 5), the cell voltage increased with a lower methanol solution flow rate, and decreased with a higher methanol solution flow rate. In all methanol solution and airflow rates, the cell voltage fluctuation further decreased in higher current densities.

Figures 9 and 10 show the exhaust volumes of $\mathrm{CO}_{2}$ slugs, product water accumulations with an anode depth of $1.2 \mathrm{~mm}$ and a cathode depth of $2 \mathrm{~mm}$, respectively. Compared with both anode and 
cathode depths of $2 \mathrm{~mm}$ in each methanol and air flow rate (in Fig. 6), the exhaust volume per $\mathrm{CO}_{2}$ slug decreased, and the exhaust volume of $\mathrm{CO}_{2}$ slugs per unit time increased except with a higher methanol flow rate and a lower air flow rate. In Fig. 9, when the methanol solution flow rate increased, both the exhaust volume per $\mathrm{CO}_{2}$ slug and the exhaust volume of $\mathrm{CO}_{2}$ slugs per unit time decreased. It appears that, when the anode channel becomes shallower, the flow velocity of the methanol solution increases, and then $\mathrm{CO}_{2}$ slugs are ejected rapidly, before they coalesce. With a lower methanol solution flow rate, the electrode reaction becomes more active. However, it is considered that, with a higher methanol solution flow rate, the crossover occurred, so power performance decreased significantly. In Fig. 10, with a higher methanol solution flow rate and a lower airflow rate, despite the crossover in which the power performance decreased, the exhaust volume of water accumulations per unit time did not increase significantly. It seems that, crossover mainly occurs near the inlet of the anode channel, with a shallower anode depth. Since the methanol solution and the air flowed in opposite directions, the methanol solution moved from the vicinity of the inlet of the anode channel to the vicinity of the exhaust of the cathode channel by crossover. It is considered that, the moved methanol solution did not remain in the cathode channel as droplets, and was ejected with the airflow.

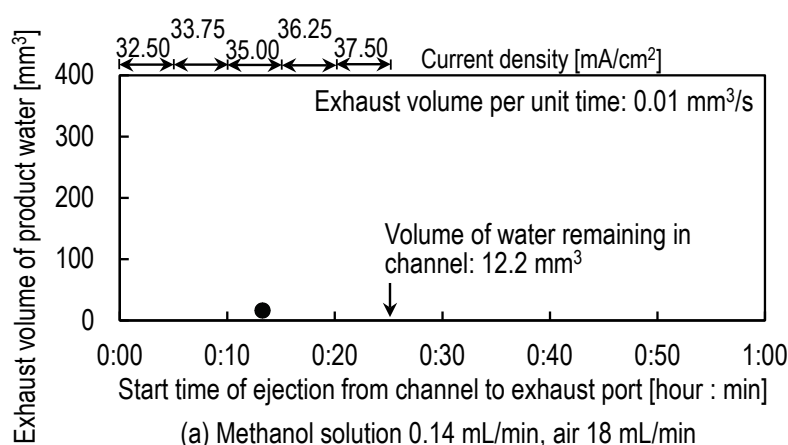

(a) Methanol solution $0.14 \mathrm{~mL} / \mathrm{min}$, air $18 \mathrm{~mL} / \mathrm{min}$

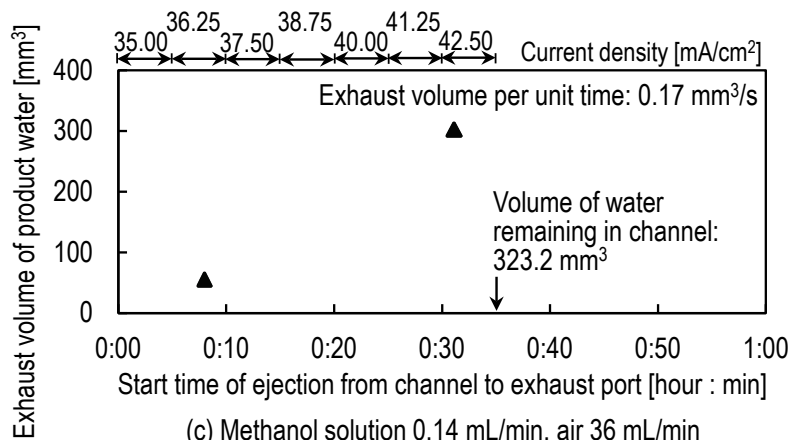

(c) Methanol solution $0.14 \mathrm{~mL} / \mathrm{min}$, air $36 \mathrm{~mL} / \mathrm{min}$

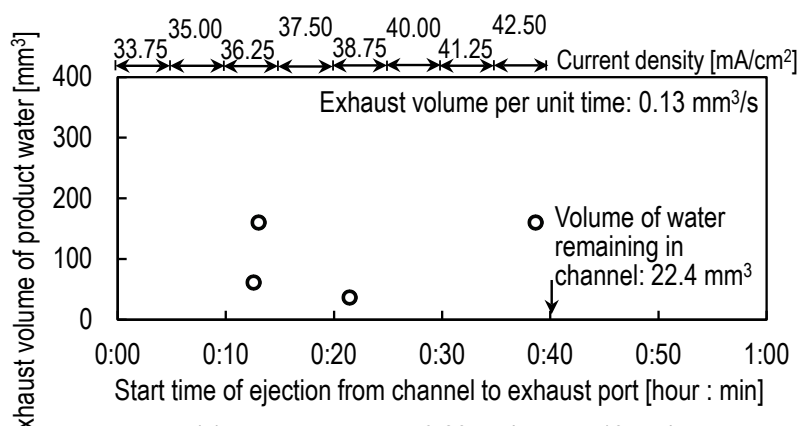

(b) Methanol solution $0.28 \mathrm{~mL} / \mathrm{min}$, air $18 \mathrm{~mL} / \mathrm{min}$

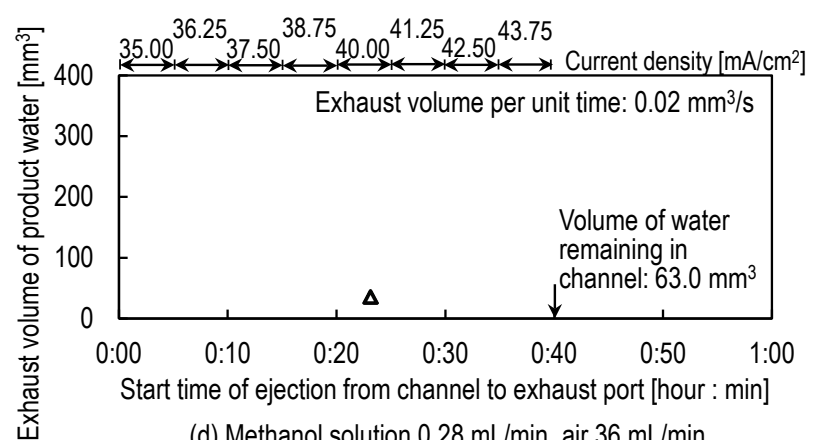

(d) Methanol solution $0.28 \mathrm{~mL} / \mathrm{min}$, air $36 \mathrm{~mL} / \mathrm{min}$

Fig. 7. Exhaust volume of product water accumulations with both anode and cathode depths of $2 \mathrm{~mm}$

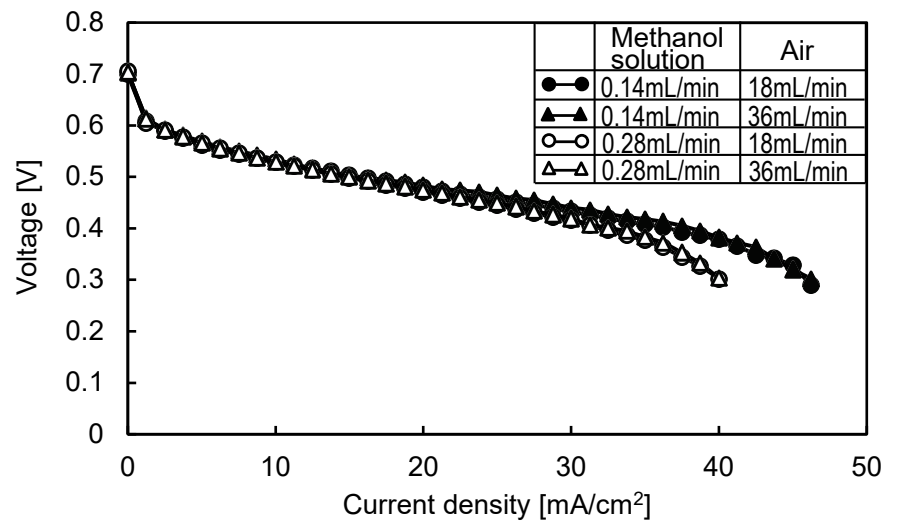

Fig. 8. Cell power performance with anode depth of $1.2 \mathrm{~mm}$ and cathode depth of $2 \mathrm{~mm}$ 


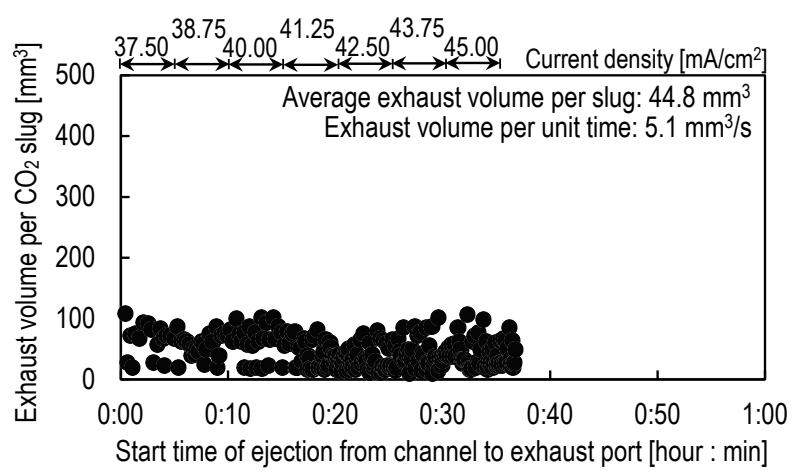

(a) Methanol solution $0.14 \mathrm{~mL} / \mathrm{min}$, air $18 \mathrm{~mL} / \mathrm{min}$

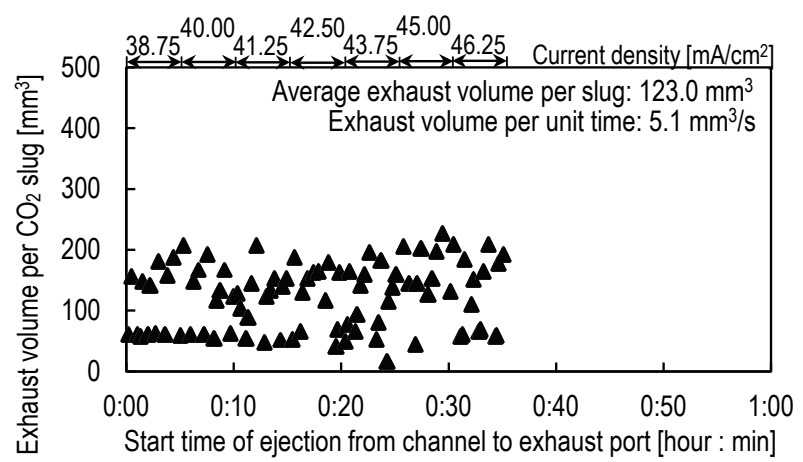

(c) Methanol solution $0.14 \mathrm{~mL} / \mathrm{min}$, air $36 \mathrm{~mL} / \mathrm{min}$

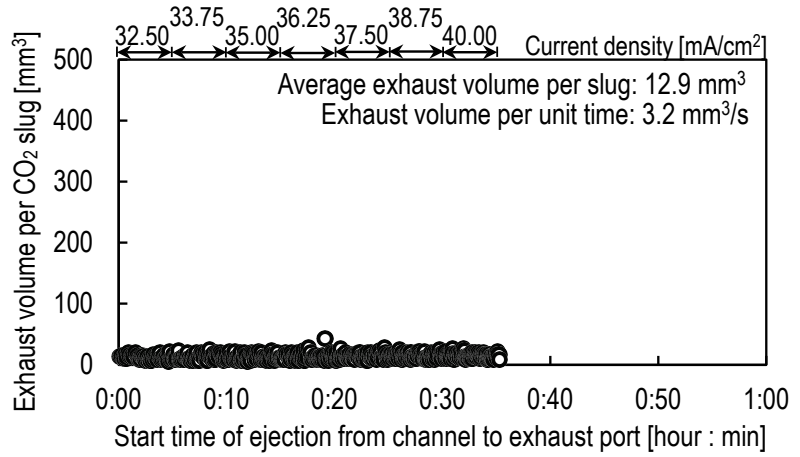

(b) Methanol solution $0.28 \mathrm{~mL} / \mathrm{min}$, air $18 \mathrm{~mL} / \mathrm{min}$

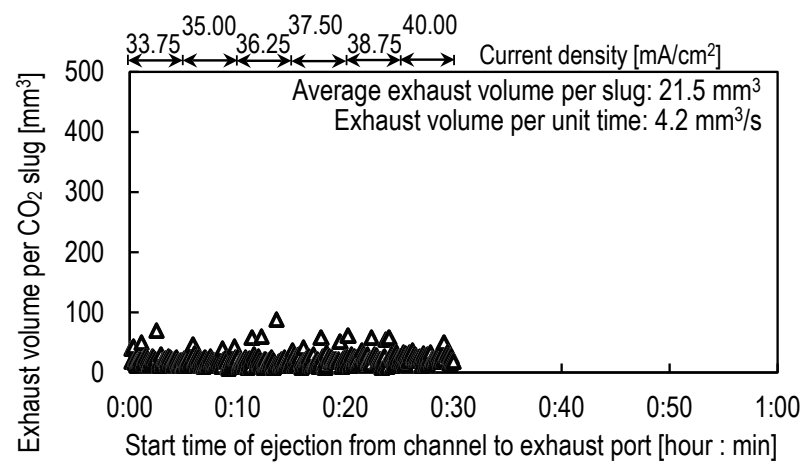

(d) Methanol solution $0.28 \mathrm{~mL} / \mathrm{min}$, air $36 \mathrm{~mL} / \mathrm{min}$

Fig. 9. Exhaust volume of $\mathrm{CO}_{2}$ slugs with anode depth of $1.2 \mathrm{~mm}$ and cathode depth of $2 \mathrm{~mm}$
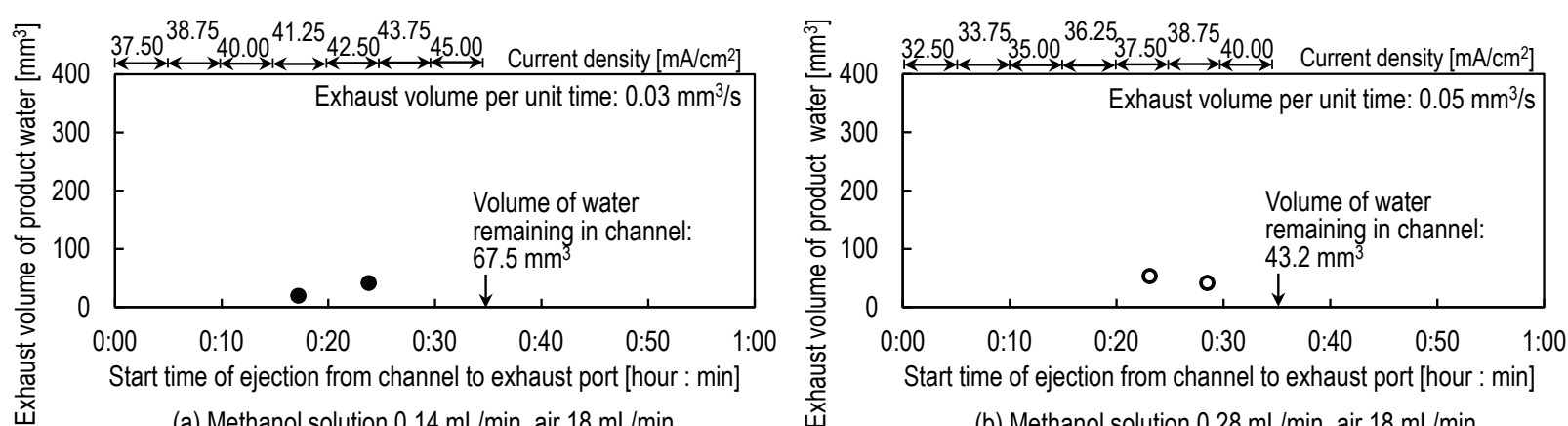

(a) Methanol solution $0.14 \mathrm{~mL} / \mathrm{min}$, air $18 \mathrm{~mL} / \mathrm{min}$

(b) Methanol solution $0.28 \mathrm{~mL} / \mathrm{min}$, air $18 \mathrm{~mL} / \mathrm{min}$
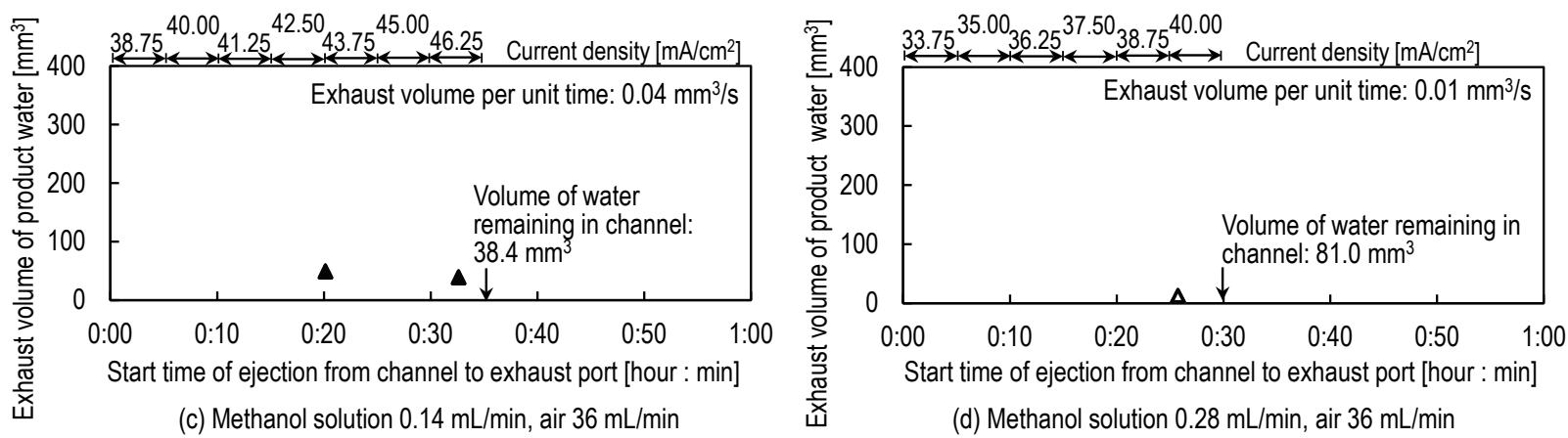

Fig. 10. Exhaust volume of product water accumulations with anode depth of $1.2 \mathrm{~mm}$ and cathode depth of $2 \mathrm{~mm}$

\section{Conclusion}

Using a transparent DMFC with serpentine channels, this study investigated the relationship between the behaviours of the $\mathrm{CO}_{2}$ slugs in the anode channel as well as the product water accumulations in the cathode channel on cell voltage fluctuation, in high current density. It then examined the exhaust volumes of the $\mathrm{CO}_{2}$ slugs and the product water accumulations from 
channels against time. The following major results were obtained:

1) As $\mathrm{CO}_{2}$ slugs were ejected from the anode channel through the exhaust port, cell voltage rose. Then while $\mathrm{CO}_{2}$ slugs were not being ejected through the exhaust port, cell voltage dropped. Thus, cell voltage fluctuated.

2) When methanol solution flow increased, small $\mathrm{CO}_{2}$ slugs were ejected from the channel through the exhaust port at frequent intervals, reducing cell voltage fluctuation.

3) Similarly, with a shallower anode depth, smaller $\mathrm{CO}_{2}$ slugs were ejected at shorter intervals, further decreasing cell voltage fluctuation. Cell power performance increased with a lower methanol solution flow rate, but decreased with a higher methanol solution flow rate, due to crossover.

\section{Acknowledgments}

I wish to thank graduate school students Mr Hirokazu Shimizu and Mr Ryuta Inagaki, and undergraduate school student Mr Daisuke Miyajima and Mr Atsuhiro Tamamura, of Meijo University at that time, for fruitful cooperation during our experimental work.

\section{References}

[1] Argyropoulos, P., Scott, K., Taama, W. M., Carbon dioxide evolution patterns in direct methanol fuel cells, Electrochimica Acta, Vol. 44, pp. 3575-3584, 1999.

[2] Burgmann, S., Blank, M., Wartmann, J., Heinzel, A., Investigation of the effect of $\mathrm{CO}_{2}$ bubbles and slugs on the performance of a DMFC by means of leaser-optical flow measurements, Energy Procedia, Vol. 28, pp. 88-101, 2012.

[3] Calabriso, A., Borello, D., Romano, G. P., Cedola, L., Zotto, L. D., Santori, S. G., Bubbly flow mapping in the anode channel of a direct methanol fuel cell via PIV investigation, Applied Energy, Vol. 185, Part 2, pp. 1245-1255, 2017.

[4] Hsieh, S., Wu, H., Her, B., A novel design for a flow field configuration, of a direct methanol fuel cell, Journal of Power Sources, Vol. 195, pp. 3224-3230, 2010.

[5] Liao, Q., Zhu, X., Zheng, X., Ding, Y., Visualization study on the dynamics of $\mathrm{CO}_{2}$ bubbles in anode channels and performance of a DMFC, Journal of Power Sources, Vol. 171, pp. 644-651, 2007.

[6] Lu, G. Q., Wong, C. Y., Electrochemical and flow characterization of a direct methanol fuel cell, Journal of Power Sources, Vol. 134, pp. 33-40, 2004.

[7] Murakami, K., Nakashima, K., Murakami, Y., Experimental Development of a Small Transparent Direct Methanol Fuel Cell, Journal of Japan Society for Design Engineering, Vol. 46, No. 8, pp. 439-442, 2011 (in Japanese).

[8] Nakashima, K., Shimizu, H., Inagaki, R., Effect of Flow Channel Size on Carbon Dioxide and Product Water Exhausts in a Small Direct Methanol Fuel Cell, Proceedings of the 6th European Fuel Cell Piero Lunghi Conference, pp. 157-158, 2015.

[9] Nakashima, K., Carbon Dioxide and Product Water Exhausts in a Small Direct Methanol Fuel Cell with Different Sizes of Serpentine Channels, Proceedings of the 7th European Fuel Cell Piero Lunghi Conference, pp. 343-344, 2017.

[10] Scott, K., Taama, W. M., Argyropoulos, P., Engineering aspects of the Direct methanol fuel cell system, Journal of Power Sources, Vol. 79, pp. 43-59, 1999.

[11] Yang, H., Zhao, T. S., Effect of anode flow field design on the performance of liquid feed direct methanol fuel cells, Electrochimica Acta, Vol. 50, pp. 3243-3252, 2005.

[12] Yang, H., Zhao, T. S., Ye, Q., In situ visualization study of $\mathrm{CO}_{2}$ gas bubble behaviour in DMFC anode flow fields, Journal of Power Sources, Vol. 139, pp. 79-90, 2005.

Manuscript received 17 July 2019; approved for printing 19 September 2019 